\title{
Treatment of Retained Fetal Membranes: Comparison of the Postpartum Period after Routine Treatment or Routine Treatment Including an Additional Phytotherapeutic Substance in Dairy Cattle in Switzerland
}

\author{
Benjamin Biner1,2, Men Bischoff' ${ }^{1}$, Franziska Klarer ${ }^{3}$, Fritz Suhner ${ }^{4}$, Jürg Hüsler ${ }^{5}$, \\ Gaby Hirsbrunner ${ }^{2}$ \\ ${ }^{1}$ Clinica Alpina, Scuol, Switzerland \\ ${ }^{2}$ Clinic for Ruminants, Vetsuisse Faculty, University of Berne, Berne, Switzerland \\ ${ }^{3}$ Unit of Phytopharmacy, Institute of Biotechnology, Zürich University of Applied Sciences, Wädenswil, Switzerland \\ ${ }^{4}$ Rena Handels AG, Hindelbank, Switzerland \\ ${ }^{5}$ Institute of Mathematical Statistics and Actuarial Science, University of Berne, Berne, Switzerland \\ Email: gaby.hirsbrunner@vetsuisse.unibe.ch
}

Received 21 March 2015; accepted 17 April 2015; published 20 April 2015

Copyright (C) 2015 by authors and Scientific Research Publishing Inc.

This work is licensed under the Creative Commons Attribution International License (CC BY). http://creativecommons.org/licenses/by/4.0/

(c) (i) Open Access

\footnotetext{
Abstract

Background: The therapy of retained fetal membranes (RFM) is a controversial subject. In Switzerland, intrauterine antibiotics are routinely administered although their effect on fertility parameters is questionable. The objective of this study was to compare the post-partal period after a routine treatment of RFM in 2 groups: one group received a placebo additionally (A), whereas the other group received a phytotherapeutic substance (lime bark) (B) additionally. The routine treatment of RFM included an attempt to manually remove the fetal membranes (for a maximum of $5 \mathrm{~min}$ ), intramuscular administration of oxytetracycline and intrauterine treatment with tetracycline. In case of an elevated rectal temperature $\left(>39.0^{\circ} \mathrm{C}\right)$, an additional non-steroidal inflammatory drug was allowed. Methods: Cows undergoing caesarean section, suffering from prolapse of the uterus, deep cervical or vaginal injuries, hypocalcaemia, and illnesses during the last 14 days before calving were excluded. Cows had to be more than $\mathbf{2 6 5}$ days pregnant. Only cows that were artificially inseminated after RFM were included. Group stratification was done according to the last number on the ear tag (even/uneven) with $(n=50)$ cows in group $A$ and $(n=55)$ cows in group B. Results: The number of treatments after the initial treatment of RFM was not significantly different between groups. The median interval from calving to the first insemination was $\mathbf{7 7}$ days 
in group A compared to 82 days in group B $(p=0.72)$. The number of AI's until conception was not significantly different between groups. The median number of days open was 89 days in group $A$ compared to 96 days in group $B(p=0.57)$. The culling rate was not significantly different between groups. Conclusion: There was neither a difference between the groups concerning therapies within the first 50 days after RFM nor concerning the subsequent fertility variables.

\section{Keywords}

\section{Cattle, Retained Fetal Membranes, Phytotherapy, Fertility}

\section{Introduction}

The incidence of retained fetal membranes (RFM) ranges from $4 \%$ to $11 \%$ of all calvings in a herd [1] with failure to expulse the fetal membranes within 12 to 24 hours after calving [2]-[4]. Following RFM, the uterus becomes contaminated with bacteria [5]. This has a negative impact on reproductive performance in cattle [5] including delayed uterine involution, a prolonged interval to first service [6] [7], an increased number of services per conception [8], a decreased conception rate [9] and a prolonged interval of days open [5]-[7]. Furthermore, mastitis, ketosis and milk production losses may occur [10]-[12]. A meta-analysis of different studies showed that RFM is associated with 2 to 3 more days to first service; the conception rate at the first service following RFM is $4 \%-10 \%$ lower, resulting in a 6 - 12 day prolonged interval to conception [3]. One study even showed a 22\% lower conception rate at first service, resulting in a 29 day longer service interval [13]. There are many risk factors known for RFM [5], such as induced parturition [14], shortened gestation length [15], abortion [16], twinning [13] [17], dystocia [14] [18], caesarean section [14], nutritional deficiencies (selenium, vitamin E, and carotene) [19] [20], infectious agents such as BVD-virus [21], and immune-suppression [22]. It has been estimated that cows suffering from RFM and clinical metritis produce 300 - $500 \mathrm{~kg}$ less milk compared with unaffected herd mates, based on a 305 day corrected milk yield [23]. The UK dairy industry loses approximately 16 million pounds a year due to cows affected by metritis/endometritis following RFM [24].

The treatment of RFM is a controversial subject [2]. Bolinder and coworkers (1988) showed that $100 \%$ of the cows at 3 weeks postpartum and $37 \%$ of the cows at 5 weeks postpartum showed pathogenic bacteria in the uterus after the manual removal of the placenta compared to $37 \%$ and $12 \%$ respectively, in cows without manual removal [25]. Drillich et al. demonstrated that $84.3 \%$ of the cows after manual removal of the placenta developed fever [26]. Furthermore, remnants of cotyledons were found on caruncles, and hemorrhages and thrombi could be seen microscopically in cows after assumed removal of RFM [4]. Nevertheless, the manual removal of RFM together with the administration of tetracycline boli is still the routine treatment in Switzerland [27], as well as in other countries [5]. Different studies recommended the use of tetracycline boli due to its broad antibacterial spectrum and its ability to retain its antibacterial properties in the presence of organic material [28]-[30]. However, the administration of intrauterine antibiotics did not reduce the incidence of metritis following RFM and could not improve fertility parameters [23]. Switzerland has a long history of using phytotherapeutic drugs in veterinary medicine [31]. The "Reinigungstrank Natürlich" (RN, Fritz Suhner Rena Handels AG, Hindelbank, Switzerland) used in this study was first produced in 1937 (Suhner, personal communication). The RN consists of lime bark (tilia cordata/tilia platyphyllos). The production of RN is man-made by Fritz Suhner III and his wife: the cambium and the cortex need to be separated from the rest of the trunk. The bark then gets stored to dry for six months, before grinding it to powder (Suhner, personal communication). The drug was registered in 1940 (Swissmedic registration-number 10'175) as one of the first phytotherapeutic substances ever [32]. Different studies described the ingredients of lime bark. The tanning agents are ellagic acid, gallitannine, gallic acid, and protocatechuic acid. Different organic acids were found in lime bark like: aesculin, fraxetin8-beta-glucopyranosid, resin acid and linoleic [33] [34]. Lime bark has been used throughout history to treat gunshot wounds, eye inflammations, burns and ulcerations [33]. It can be given to cows with concentrates or brewed up as a "tea". There are more than 1000 farms all over Switzerland using RN (Suhner, personal communication). RN is used to stimulate the discharge of lochia resulting in improved fertility parameters (CliniPharm, Swissmedic 10175). Until now, there is no scientific literature available about the efficacy of RN. Therefore, the 
objective of this study was to compare a routine treatment of RFM in 2 groups: one group received RN additionally, whereas the other group received a placebo additionally. Our hypothesis was that the days open in the RN-group would be 5\% shorter than in the placebo group and secondly that number of gynaecological treatments during the first 50 days after parturition would decrease in the RN group. If so, routine treatment could be replaced by RN exclusively in a follow-up study.

\section{Material and Methods}

\subsection{Animals, Including and Excluding Criteria}

The study was conducted on dairy farms in different parts of Switzerland. Multiparous Brown Swiss cows and their crossbreeds suffering from RFM were included. The farms were free stall facilities or tie stalls and all the cows had access to pasture.

Cows undergoing caesarean section, suffering from prolapse of the uterus, deep cervical or vaginal injuries, hypocalcaemia, and illnesses during the last 14 days before calving were excluded. Cows had to be more than 265 days pregnant, and only one cow per day and per farm was included to prevent cluster effects. Only cows that were artificially inseminated after RFM were included.

\subsection{Study Design and Treatment}

A total of five veterinary practices were involved in the study, lasting from September 2012 to March 2014. These practices mainly treated cows with seasonal calvings (beginning of September to end of January). The standard therapy for a cow with RFM was: recording the rectal temperature, an attempt to manually remove the placenta (maximal time $5 \mathrm{~min}$ ), systemic administration of oxytetracycline intramuscularly (i.m.) (10 mg/kg of body weight SID Engemycin ${ }^{\circledR} 10 \%$, MSD Animal Health GmbH, Luzern, Switzerland) and intrauterine treatment with tetracycline ( 2 boles with 2 g each, Tetran ${ }^{\circledR}$ forte, Dr E. Graeub AG, Bern, Switzerland). In case of an increased rectal temperature (>39.0), an additional non-steroidal anti-inflammatory drug was allowed. A rectal examination of the uterus was optional. All first treatments were performed by a veterinarian between 8 and 96 hours postpartum. Cows were randomly assigned to routine treatment and placebo for ten days (A, even ear tag) or routine treatment and RN (B, uneven ear tag) for ten days. The placebo consisted of dry, ground apples (produced by Häflinger mill in Gipf/Oberfrick, Switzerland). The RN consists of lime bark (tilia cordata/tilia platyphyllos). The placebo and RN were delivered in neutral packages of $400 \mathrm{~g}$ (marked with “A” or "B”) and it was not possible to tell the ingredients apart. The placebo or RN was fed by the farmer. The daily dose was 40 g using a standard cup and the substances were given for 10 days together with concentrate.

The veterinarian had to fill out a questionnaire (identification of the cow, state of the placenta, rectal body temperature, treatment group, additional treatment). Part of this questionnaire was left on the farm. Further treatments and gynaecological examinations, dates of inseminations and pregnancy examination had to be documented by the farmer. Once pregnancy was confirmed or at the latest when the cow was calving again, the questionnaire was collected by the author and the data transferred to an Excel sheet.

\subsection{Variables Evaluated}

Pregnancy duration and calving assistance were recorded. Calving assistance was categorized as $0=$ none, $1=$ light, 2 = medium (1 man), 3 = strong ( 2 men), 4 = veterinary assistance. The primary endpoint compared between the groups was “days open”. Further variables were also recorded: the interval from calving to first insemination, number of AI's until conception, subsequent treatment of uterus (local administration of antibiotics or disinfectants); the reasons for culling during the lactation following RFM.

\subsection{Statistics}

Metric data are described with median and quartiles. This data from both groups are compared with the MannWhitney test for independent groups. Categorical data are described with percentages of the categories. This data from both groups are compared with the chi-squares test or Fisher's exact test, deriving the p-values by exact calculations if necessary. 


\section{Results}

\subsection{Animals and Farms}

A total of $n=50$ cows in group A and $n=55$ cows in group B were included. The descriptive measures for the following parameters: age of cows (years), number of cows/farm, yearly milk yield/cow (kg), duration of pregnancy, treatment at hours p.p., interval from calving to first insemination, number of AI's, and days open for both groups are listed in Table 1 . There was no significant difference found between the groups for all parameters listed. The type of stall was either a free stall (A/B: $n=26 / n=18)$ or a tie stall (A/B: $n=19 / n=33)$, a significant difference was calculated $(\mathrm{p}=0.03)$.

\subsection{Calving/Placenta}

Calving assistance is listed in Table 2. There were no significant differences between the groups $(\mathrm{p}=0.69)$. In each group, $n=2$ cows had been suffering from retained placenta after the previous calving $(p=0.92)$. Degree of placental retention and removability is also listed in Table 2 .

Table 1. Median values (25\%/75\%) and p-values of the groups placebo (A) versus RN (B). There were no significant differences between the groups.

\begin{tabular}{|c|c|c|c|}
\hline Parameters & Group A & Group B & p-value (2-sided) \\
\hline Age of cows (years) & $5(3 / 6)$ & $4(3 / 5)$ & 0.162 \\
\hline Number of cows/farm & $19(14 / 30)$ & $20(15 / 28)$ & 0.895 \\
\hline Yearly milk yield/cow (kg) & $6800(6500 / 7000)$ & $6500(6300 / 7000)$ & 0.181 \\
\hline Duration of pregnancy (days) & $290.5(286 / 295)$ & $291(283 / 294)$ & 0.344 \\
\hline Treatment p.p. (hours) & $20(12 / 24)$ & $18(12 / 24)$ & 0.862 \\
\hline Calving to $1^{\text {st }}$ insemin. (days) & $77(58 / 104.5)$ & $82(66.5 / 96)$ & 0.722 \\
\hline Number of AI's & $1(1 / 2)$ & $1(1 / 2)$ & 0.588 \\
\hline Days open & $89(65 / 128)$ & $96(71 / 120)$ & 0.566 \\
\hline
\end{tabular}

Table 2. Number of cows and p-values of the groups placebo (A) versus RN (B). There were no significant differences between the groups as to calving aid, placenta and additional first therapy.

\begin{tabular}{|c|c|c|c|}
\hline Parameters & Group A & Group B & p-value (2-sided) \\
\hline Calving aid & & & 0.69 \\
\hline unassisted & 28 & 31 & \\
\hline light & 11 & 12 & \\
\hline 1 man & 8 & 5 & \\
\hline 2 men & 1 & 2 & \\
\hline veterinarian & 2 & 5 & \\
\hline Placenta & & & 0.60 \\
\hline fully retained & 24 & 32 & \\
\hline partially retained & 26 & 23 & \\
\hline easily removable & 22 & 26 & \\
\hline not removable & 28 & 29 & \\
\hline Additional $1^{\text {st }}$ therapy & & & 0.60 \\
\hline steroids & 7 & 5 & \\
\hline NSAIDS & 8 & 11 & \\
\hline oxytocin & 3 & 7 & \\
\hline
\end{tabular}




\subsection{Therapy/Outcome}

There were 12 cows in group A with an elevated body temperature at first therapy compared to 11 cows in group B ( $\mathrm{p}=0.62)$. All cows received oxytetracycline i.m. and intrauterine treatment with tetracycline boles. Additional first therapies are listed in Table 2. The second therapy was performed 2 days after calving (median; $2 / 4$ days $=0.25 / 0.75$ quartiles) in group $A ; 3$ days (median; $2 / 3.5$ days $=0.25 / 0.75$ quartiles) in group $B$. Again, cows received tetracycline boles $(A / B: n=28 / n=29)$, oxytetracycline i.m. (A/B: $n=12 / n=21)$; anti-inflammatory drugs $(A / B: n=4 / n=6)$; differences between the groups were not significant $(p=0.052)$. There was no significant difference $(\mathrm{p}=0.33$ ) between the groups as to number of treatments concerning the uterus (irrigation, PGE2, $\left.\mathrm{PGF}_{2 \alpha}\right)$ within the first 50 days after calving $(\mathrm{A} / \mathrm{B}: \mathrm{n}=14 / \mathrm{n}=11)$.

\subsection{Fertility Variables}

The interval between calving and first insemination was 77 days (median; 0.25/.75 quartiles: 58/104.5 days) in group A compared to 82 days $(66.5 / 96$ days) in group B ( $\mathrm{p}=0.72)$. The number of AI's until conception was 1 $(1 / 2)$ in group A compared to $1(1 / 2)$ in group $B(p=0.59)$. Days open were 89 days $(65 / 128$ days $)$ in group A compared to 96 days $(71 / 120$ days) in group $B(p=0.57)$ (Table 1$)$. In group A, 1 cow was culled for fertility reasons compared to 4 cows in group $B$. There was no significant difference between the groups $(p=0.21)$. In group A, 6 cows were culled for other reasons compared to 7 in group B $(p=0.91)$.

\section{Discussion}

Public awareness of the prudent use of antibiotics in the dairy and food industry is steadily improving and the demand for alternative therapies is increasing [35].

The Swiss government is developing a concept called StAR (strategies against antimicrobial resistances). Our study aimed to use a phytotherapeutic drug (RN) to complement antibiotic therapy and after positive evaluation, to replace antibiotics in a follow-up study. Unfortunately, there was no significant difference as to number of treatments and as to fertility variables evaluated between the groups. Can we, therefore, deduce that RN did not exert a positive influence? Almost 100 farmers participated in the study; not all of them were convinced of the potential benefit of RN. The personal feedback from farmers which had already used alternative medicine was that RN had a positive effect on cows with RFM, whereas sceptical owners did not see an advantage in using a phytotherapeutic drug. Socioeconomic factors influence the way in which farmers use antimicrobials [36] and this may also hold true for administering phytotherapeutic substances. The aim of reducing the amount of antibiotics used in farm animal medicine and using alternative medicine instead, requires time in order to raise awareness. Although this work did not demonstrate a benefit of using RN, its strength was to show the farmers a different way of treating animals. A follow-up study will focus on farmers' willing to reduce the amount of antibiotics in cows with RFM and using RN in their place, assuming that cows are not febrile and in good general condition.

\section{Acknowledgements}

We thank MSD Animal Health GmbH, Luzern, Switzerland and Dr. E. Graeub AG Bern, Switzerland for supporting this study. Thanks to Fritz Suhner for sharing his knowledge about RN and for helping us with the substance. We also thank the supporting veterinarians.

\section{References}

[1] Eiler, H. (1997) Retained Placenta, in Current Therapy in Large Animal Theriogenology. Youngquist, R., Ed., Saunders, Philadelphia, London, Toronto, 340-348.

[2] Drillich, M., Pfützner, A., Sabin, H.J., Sabin, M. and Heuwieser, W.M. (2003) Comparison of Two Protocols for the Treatment of Retained Fetal Membranes in Dairy Cattle. Theriogenology, 59, 951-960. http://dx.doi.org/10.1016/S0093-691X(02)01132-9

[3] Fourichon, C., Seegers, H. and Malher, X. (2000) Effect of Disease on Reproduction in the Dairy Cow: A Meta-Analysis. Theriogenology, 53, 1729-1759. http://dx.doi.org/10.1016/S0093-691X(00)00311-3

[4] Paisley, L.G., Michelson, W.D. and Anderson, P.B. (1986) Mechanisms and Therapy for Retained Fetal Membranes and Uterine Infections of Cows; A Review. Theriogenology, 25, 353-381. 
http://dx.doi.org/10.1016/0093-691X(86)90045-2

[5] Sheldon, I.M., Lewis, G.S., LeBlanc, S. and Gilbert, R.O. (2006) Defining Postpartum Uterine Disease in Cattle. Theriogenology, 65, 1516-1530. http://dx.doi.org/10.1016/j.theriogenology.2005.08.021

[6] Beagley, J.C., Whitman, K.J., Baptiste, K.E. and Scherzer, J.J. (2010) Physiology and Treatment of Retained Fetal Membranes in Cattle. Journal of Veterinary Internal Medicine, 24, 261-268. http://dx.doi.org/10.1111/j.1939-1676.2010.0473.x

[7] Stevens, R.D. and Dinsmore, R.P. (1997) Treatment of Dairy Cows at Parturition with Prostaglandin F2a or Oxytocin for Prevention of Retained Fetal Membranes. Journal of the American Veterinary Medical Association, 211, 12801284.

[8] Holt, L.C., Whittier, W.D., Gwazdauskas, F.C. and Vinson, W.E. (1989) Early Postpartum Reproductive Profiles in Holstein Cows with Retained Placenta and Uterine Discharges. Journal of Dairy Science, 72, 533-539. http://dx.doi.org/10.3168/jds.S0022-0302(89)79137-2

[9] McDougall, S. (2001) Effect of Intrauterine Antibiotic Treatment on Reproductive Performance of Dairy Cows Following Periparturient Disease. New Zealand Veterinary Journal, 49, 150-158. http://dx.doi.org/10.1080/00480169.2001.36223

[10] Schukken, Y.H. (1989) Retained Placenta and Mastitis. Cornell Veterinarian, 79, 129-131.

[11] Bruun, J., Ersboll, A.K. and Alban, L. (2002) Risk Factors for Metritis in Danish Dairy Cows. Preventive Veterinary Medicine, 54, 179-190. http://dx.doi.org/10.1016/S0167-5877(02)00026-0

[12] Melendez, P., Donovan, G.A., Risco, C.A., Littell, R. and Goff, J.P. (2003) Effect of Calcium-Energy Supplements on Calving-Related Disorders, Fertility and Milk Yield during the Transition Period in Cows Fed Anionic Diets. Theriogenology, 60, 843-854. http://dx.doi.org/10.1016/S0093-691X(03)00103-1

[13] Goshen, T. and Shpigel, N.Y. (2006) Evaluation of Intrauterine Antibiotic Treatment of Clinical Metritis and Retained Fetal Membranes in Dairy Cows. Theriogenology, 66, 2210-2218. http://dx.doi.org/10.1016/j.theriogenology.2006.07.017

[14] Terblanche, H.M., Kritzinger, L.J. and van Heerden, J.S. (1976) Induced Parturition in Cattle. 1. Clinical Studies. Journal of the South African Veterinary Association, 47, 113-115.

[15] Muller, L.D. and Owens, M.J. (1974) Factors Associated with the Incidence of Retained Placentas. Journal of Dairy Science, 57, 725-728. http://dx.doi.org/10.3168/jds.S0022-0302(74)84956-8

[16] Joosten, I., Van Eldik, P., Elving, L. and Van der Mey, G.J.W. (1987) Factors Related to the Etiology of Retained Placenta in Dairy Cattle. Animal Reproduction Science, 14, 251-262. http://dx.doi.org/10.1016/0378-4320(87)90015-7

[17] Erb, R.E., Hinze, P.M., Gildow, E.M. and Morrison, R.A. (1958) Retained Fetal Membranes: The Effect on Prolificacy of Dairy Cattle. Journal of the American Veterinary Medical Association, 133, 489-496.

[18] Rajala, P.J. and Grohn, Y.T. (1998) Effects of Dystocia, Retained Placenta, and Metritis on Milk Yield in Diary Cows. Journal of Dairy Science, 81, 3172-3181. http://dx.doi.org/10.3168/jds.S0022-0302(98)75883-7

[19] Cook, J.G. and Green, M.J. (2007) Reduced Incidence of Retained Fetal Membranes in Dairy Herds Supplemented with Iodine, Selenium and Cobalt. Veterinary Record, 161, 625-626. http://dx.doi.org/10.1136/vr.161.18.625

[20] Kankofer, M., Albera, E., Feldmann, M., Gundling, N. and Hoedemaker, M. (2010) Comparison of Antioxidative/Oxidative Profiles in Blood Plasma of Cows with and without Retained Fetal Placental Membranes. Theriogenology, 4, 1385-1395. http://dx.doi.org/10.1016/j.theriogenology.2010.06.009

[21] Niskanen, R., Emanuelson, U., Sundberg, J., Larsson, B. and Alenius, S. (1995) Effects of Infection with Bovine Virus Diarrhoea Virus on Health and Reproductive Performance in 213 Dairy Herds in One Country in Sweden. Preventive Veterinary Medicine, 23, 229-237. http://dx.doi.org/10.1016/0167-5877(94)00437-N

[22] Curtis, C.R., Erb, H.N. and Sniffen, C.J. (1996) Path Analysis of Dry Period Nutrition, Postpartum Metabolic and Reproductive Disorders, and Mastitis in Holstein Cows. Veterinary Record, 139, 465-471.

[23] Laven, R.A. and Peters, A.R. (1996) Bovine Retained Placenta: Aetiology, Pathogenesis and Economic Loss. Veterinary Record, 139, 465-471. http://dx.doi.org/10.1136/vr.139.19.465

[24] McNaughton, A.P. and Murray, R.D. (2009) Structure and Function of the Bovine Fetomaternal Unit in Relation to the Causes of Retained Fetal Membranes. Veterinary Record, 165, 615-622. http://dx.doi.org/10.1136/vr.165.21.615

[25] Bolinder, A., Sequin, B., Kindahl, H., Bouley, D. and Otterby, D. (1988) Retained Fetal Membranes in Cows: Manual Removal versus Nonremoval and Its Effect on Reproductive Performance. Theriogenology, 30, 45-56. http://dx.doi.org/10.1016/0093-691X(88)90262-2

[26] Drillich, M., Mahlstedt, M., Reichert, U. and Tenhagen, B.-A. (2006) Strategies to Improve the Therapy of Retained Fetal Membranes in Dairy Cows. Journal of Dairy Science, 89, 627-635. 
http://dx.doi.org/10.3168/jds.S0022-0302(06)72126-9

[27] Hehenberger, E.M., Doherr, M.G., Bodmer, M., Steiner, A. and Hirsbrunner, G. (2015) Diagnose und Therapie von Nachgeburtsverhalten, puerperaler Metritis und klinischer Endometritis beim Rind: Ergebnisse der Online-Umfrage bei Schweizer Tierärzten. I Nachgeburtsverhalten. Schweiz Archiv Tierheilk, Accepted for Publication.

[28] Gustafsson, B. (1984) Therapeutic Strategies Involving Antimicrobial Treatment of the Uterus in Large Animals. Journal of the American Veterinary Medical Association, 185, 1194-1198.

[29] Montes, A.J. and Pugh, D.G. (1993) Clinical Approach to Postpartum Metritis. Compendium on Continuing Education for the Practising Veterinarian, 15, 1131-1137.

[30] Dinsmore, R.P., Stevens, R.D., Cattell, M.B., Salman, M.D. and Sundlof, S.F. (1996) Oxytetracycline Residues in Milk after Intrauterine Treatment of Cows with Retained Fetal Membranes. Journal of the American Veterinary Medical Association, 209, 1753-1755.

[31] Schmid, K., Ivemeyer, S., Vogl, C., Klarer, F., Meier, B., Hamburger, M. and Walkenhorst, M. (2012) Traditional Use of Herbal Remedies in Livestock by Farmers in 3 Swiss Cantons (Aargau, Zurich, Schaffhausen). Forsch Komplementmed, 19, 125-136. http://dx.doi.org/10.1159/000339336

[32] Hoffmann, R. (1989) Die Verwendung pflanzlicher Mittel zur Behandlung des Viehs, in Physiologie und Hygiene. Thesis, Zürich.

[33] Schmid, A. (1948) Pharmakologische Untersuchungen von Rinden der Cenera Tilia und Ulmus unter der Berücksichtigung des Schleim- und Gerbstoffgehalts. Thesis, Zürich.

[34] Blaschek, W., Ebel, S., Hackenthal, E., Holzgrabe, U., Keller, K., Reichling, J. and Schulz, V., Eds. (2006) Hager's Handbuch der Drogen- und Arzneistoffe. Springer, Berlin.

[35] Arlt, S. (2006) Naturheilverfahren auf dem Prüfstand. Tierärztl Umschau, 61, 332-333.

[36] Jan, J.S., McIntosh, W.A., Dean, W. and Scott, H.M. (2012) Predictors of Differences in the Perception of Antimicrobial Resistance Risk in the Treatment of Sick, At-Risk, and High-Risk Feedlot Cattle. Preventive Veterinary Medicine, 106, 24-33. http://dx.doi.org/10.1016/j.prevetmed.2012.02.012 